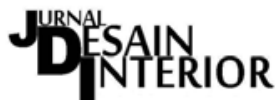

Vol. 2, No. 2, Desember 2017, pISSN 2527-2853, eISSN 2549-2985

\section{Pergeseran Makna Warna Pink dari Maskulinitas Menjadi Femininitas di Amerika Serikat Tahun 1940-1970}

\author{
Moh. Faishol Fuady \\ Program Studi Magister Desain, Institut Teknologi Bandung \\ faisolfuady@gmail.com
}

\begin{abstract}
ABSTRAK
Warna pink yang diasosiasikan dengan femininitas merupakan fenomena budaya global dan telah menjadi bagian dari gaya hidup saat ini. Fenomena tersebut merupakan hasil dari paradigma di masyarakat yang memandang warna pink sebagai warna yang tepat untuk digunakan perempuan sebagai salah satu alat utama untuk membentuk identitas diri. Namun berdasarkan sejarah, bentuk femininitas pada warna pink merupakan hasil dari proses transformasi makna yang semula berkonotasi maskulin, yang terjadi di Amerika sebanyak 3 kali antara tahun 1940 hingga akhir tahun 1970. Transformasi makna yang pertama terjadi saat Perang Dunia I dan II, terjadi transformasi sosial di masyarakat yang berpengaruh terhadap perubahan pemaknaan pada warna pink dari maskulin menjadi feminin. Transformasi makna yang ke 2 terjadi pada pertengahan dekade 1950, terjadi perubahan gaya hidup yang revolusioner hasil dari kemajuan ekonomi di Amerika, yang menyebabkan terdapat dua pemaknaan femininitas pada warna pink. Dan transformasi makna yang ke 3 terjadi antara tahun 19601970an, pemaknaan warna pink kemudian berkonotasi feminin dan cenderung bersifat masif hingga saat ini, dampak dari isu-isu dan gerakan sosial yang berkembang, diantaranya seperti gerakan feminisme, isu lingkungan, masa resesi, dan segmentasi industri. Kajian ini menggunakan metode historis dengan pendekatan sosial, yang fokus terhadap konstruksi sosial yang terbentuk melalui perubahan kondisi sosial dan perilaku sosial. Hasil analisa menunjukkan bahwa latar belakang terjadinya pergeseran makna warna pink disebabkan oleh perilaku kompetisi gender, yaitu perilaku sosial dampak dari perubahan sosial yang terjadi di Amerika serikat.
\end{abstract}

Kata kunci: warna pink; makna ganda; transformasi; kompetisi gender.

\section{ABSTRACT}

Pink that associated with femininity is a global cultural phenomenon and has become part of the current life style, it is caused by the paradigm in the society who looked at pink is the right colour to use for woman's shaping identity. But based on history, the meaning of femininity in pink is the result of transformation of meaning happens in America as much as three times between 1940 to 1970. The first transformation of meaning when World War I and II as a result of social transformation, which led to the definition of pink changes from masculin to feminine. The second transformation of meaning happenend in the mid-1950s, which cause multiple meaning of femininity in pink. While the third transformation of meaning occured between 1960-1970s resulting from the influence of social issues such as feminism movements, environmental issue, recession, and industry segmentation. These condition have an impact on changing the meaning of pink being feminine and survived up to the present. Qualitative methods with a historical approach used to present data on the development pattern of pink and its transformation. The process analysis of multiple meaning using a social appoach, focus on the social construction of society, which was formed trhough changes in social conditions and the change of social behavior. The result showed that the shifting of meaning of pink occurs as a result of social changes during World War II, which led to the occurance of gender competition behavior in America. Keywords: pink; multiple meaning; transformation; gender competition.

\section{PENDAHULUAN}

Simbol femininitas pada warna pink merupakan sebuah fenomena budaya global yang telah menjadi bagian dari gaya hidup saat ini, terbentuknya simbol tersebut akibat paradigma di 
masyarakat yang memandang warna pink sebagai warna yang tepat untuk digunakan perempuan. Disimpulkan dari Paoletti (2012), bahwa terdapat kecenderungan pada anak-anak perempuan lebih memilih benda berwarna pink dibandingkan warna lainnya, termasuk pada orang dewasa yang cenderung menyediakan kebutuhan hidup anak perempuan mereka dengan sesuatu yang berwarna pink. Pola kerja simbol membentuk cara pandang masyarakat terhadap pemaknaan femininitas pada warna pink sebagai sesuatu yang wajar dan terjadi secara alami, seperti yang diungkapkan Bourdeau (1998) bahwa kekuatan simbolik adalah suatu bentuk kekuasaan yang diberlakukan atas tubuh secara langsung dan seperti sihir, dan kekuasaan itu diberlakukan atas tubuh tanpa menggunakan kekangan fisik apapun.

Perkembangan fenomena warna pink di masyarakat saat ini disebabkan oleh aspek budaya (dalam wacana gender) serta perkembangan tren yang berpengaruh terhadap gaya hidup. Aspek budaya berperan terhadap cara pandang masyarakat dalam memaknai warna pink dengan sifat femininitas, terutama pada budaya patriarki yang menempatkan gender feminin pada posisi yang bersifat lemah/pasif dan dianggap identik dengan pigmen warna pink yang bersifat lemah/memudar. Asosiasi tersebut merupakan salah satu upaya untuk menempatkan masingmasing gender pada posisinya dengan menggunakan warna sebagai alat legitimasi, sebab pada masing-masing gender memiliki eksistensi yang bersifat relasional. Bagi Bourdeau (1998) masing-masing gender merupakan produk dari kerja konstruksi sosial yang bersifat diakritis, yaitu sekaligus bersifat teori dan praktek. Konstruksi tersebut membentuk perbedaan sifat-sifat gender maskulin dan feminin ke dalam bentuk oposisi biner, seperti kuat dan lemah, agresif dan pasif.

Tabel 1. Diferensiasi Perilaku Gender

\begin{tabular}{|c|c|}
\hline MEN are (should be) & WOMEN are (should be) \\
\hline Masculine & Feminine \\
\hline Dominant & Submissive \\
\hline Strong & Weak \\
\hline Agressive & Passive \\
\hline Intelligent & Intuitive \\
\hline Rational & Emotional \\
\hline Active (do things) & Communicative (talk about things) \\
\hline MEN like: & WOMEN like: \\
\hline Cars/technology & Shopping/make up \\
\hline Getting drunk & Social drinking with friend \\
\hline Casual sex with many partners & Committed relationship \\
\hline
\end{tabular}

Sumber: Helen MacDonald (tt). "Magazine Advertising and Gender" (Akses: htpp://mediated.or.uk/posted_documents/MagzineAdverts.html)

Sedangkan aspek tren memberi ruang terhadap pola pemaknaan warna pink dari budaya patriarki, untuk membentuk stereotype pada masyarakat sebagai sesuatu yang ideal untuk diadaptasi menjadi gaya hidup. Tren warna pink pada umumnya dibentuk, disebarkan, dan dipertahankan melalui dunia hiburan (film, musik), media massa (tv, majalah) dan fashion. Tren 
yang telah terbentuk akan menciptakan ekosistem yang saling mendukung antara perkembangan tren dan kebutuhan dari gaya hidup, yaitu industri dan permintaan pasar yang menghasilkan produk-produk konsumsi dengan segmentasi pasar perempuan.

Namun berdasarkan sejarah, sebelum abad 20 di Eropa dan Amerika warna pink cenderung diasosiasikan dengan laki-laki. Konotasi warna pink pada saat itu adalah keberanian atau semangat muda, derivasi dari warna merah yang berkonotasi berani. Sifat tersebut dalam budaya patriarki termasuk dalam kategori maskulin. Sedangkan anak perempuan yang dianggap bersifat lemah dan lembut cenderung menggunakan warna biru muda, selain juga disebabkan warna biru identik dengan warna simbolik bunda Maria di agama Katolik (Paoletti, 2012). Tren pergeseran makna tersebut dapat diamati melalui survei yang dipublikasikan majalah Time tahun 1927, disebutkan bahwa dari sepuluh toko pakaian anak-anak di Amerika, lima toko mengidentifikasi anak perempuan dengan warna pink, sisanya mengidentifikasi anak laki-laki dengan warna biru. Berikut adalah tabel identifikasi penggunaan warna pink terhadap gender:

Tabel 2. Grafik identifikasi gender di Amerika

\begin{tabular}{|c|c|c|c|}
\hline Kota & Toko & Anak laki-laki & Anak perempuan \\
\hline Boston & Filene's & Pink & Biru \\
\hline Manhattan & Best's & Pink & Biru \\
\cline { 3 - 4 } & Macy's & Biru & Pink \\
\cline { 3 - 4 } & Franklin Simon & Biru & Pink \\
\hline Philadelphia & John Wanamaker's & Biru & Pink \\
\hline Cleveland & Halle's & Biru & Pink \\
\hline Chicago & Marshall Field's & Pink \\
\hline New Orleans & Maison Blanche & Pink & Biru \\
\hline San Francisco & The White House & Pink & Biru \\
\hline Los Angeles & Bullock's & Biru & Pink \\
\hline
\end{tabular}

Sumber: Diadaptasi dari majalah Time edisi 11 November 1927

Kajian ini bertujuan untuk memetakan pola dan menganalisa proses transformasi pergeseran makna pada warna pink, dengan pendekatan historis untuk mengeksplorasi dan memaparkan aspek-aspek yang membentuk dan mempengaruhi terjadinya pergeseran makna dan proses transformasinya antara tahun 1940-1970an.

\section{HASIL PENELITIAN DAN PEMBAHASAN}

\section{A. Psikologi Warna}

Untuk melihat warna sebagai pengalaman sadar dan tidak sadar, Mahnke (1996) membaginya dalam 6 tingkatan mengenai pengalaman manusia terhadap warna, yaitu reaksi biologis terhadap stimulus warna (karakteristik yang melekat sebagai alat bertahan hidup), kesadaran kolektif (arketipe atau pola asli), kesadaran simbolisme atau asosiasi (pengalaman dari alam), pengaruh budaya dan perilaku sosial, pengaruh tren, dan hubungan personal (respon subyektifitas pribadi).

Menurut Hallock (2003) perempuan lebih peka terhadap warna sehingga mampu memberi julukan dan mengelompokkan warna lebih baik dibandingkan laki-laki. Perempuan cenderung menyebut beberapa jenis warna dengan nama buah-buahan, sedangkan laki-laki hanya menyebutkan nama warna tersebut. Laki-laki menyebut beberapa jenis warna merah-muda 
hanya dengan sebutan pink, sedangkan perempuan menyebut beberapa jenis warna merah-muda sesuai karakter warnanya, yaitu carnation, strawberry, bubblegum, magenta dan salmon. Kepekaan perempuan dalam mengelompokkan warna kemungkinan disebabkan peran masa lalu perempuan saat masa panen dan mengumpulkan makanan. Menurut Anya Hulbert dan Yazhu Ling (2007), perburuan atau mengumpulkan makanan dari lingkungan sekitar merupakan cara manusia untuk mendapatkan makanan sebelum munculnya pertanian sekitar 10.000 tahun yang lalu. Dalam kelompok pengumpul makanan, laki-laki umumnya bertugas untuk berburu sedangkan perempuan bertugas untuk mencari buah-buahan, sayuran dan tanaman. Secara psikologis kebiasaan tersebut membuat perempuan menjadi lebih peka dan terbiasa dengan warna merah dari buah yang matang dan akan fokus pada warna kemerahmerahan untuk membuat pencarian menjadi lebih mudah. Dan juga berguna untuk mengenali wajah yang memerah, yang merupakan tanda penyakit seperti demam pada anak-anak yang mereka asuh.

\section{B. Warna Simbolik}

Simbol diciptakan, dimodifikasi, dipahami dan disepakati oleh manusia sebagai salah satu alat untuk berinteraksi sesama manusia. Manusia tidak dapat lepas dari budaya simbolisme baik secara sadar maupun tidak sadar, begitu juga yang terjadi pada fenomena simbolisme warna pink serta penggunaannya. Sebab bagi Cassirer (An Essay on Man. 1944) manusia merupakan makhluk simbolik (animal simbolicum) yang pada dasarnya organisme biologis manapun tidak dapat dilepaskan dari ekosistem yang melingkupinya. "Ekosistem ini sangat bersifat khusus dan tepat bagi organisme yang bersangkutan. Setiap organisme mempunyai pengalamannya sendiri dan karena itu memiliki dunianya sendiri". Masih menurut Cassirer, bahwa dunia manusiawi meskipun mengikuti hukum-hukum biologis juga memiliki karakteristik baru yang menandai ciri khas manusia.

Lingkaran fungsional manusia tidak hanya berkembang secara kuantitatif, tetapi juga mengalami perubahan-perubahan kualitatif. Manusia mampu menemukan cara baru untuk menyesuaikan diri dengan lingkungannya. Diantara sistem reseptor dan sistem efektor yang terdapat pada semua spesies binatang, pada manusia terdapat mata rantai yang mungkin dapat kita sebut sebagai sistem simbolis. Dengan kemampuan tersebut kehidupan manusia mengalami perubahan yang sangat fundamental, manusia benar-benar hidup dalam dimensi realitas baru. Manusia tidak lagi hanya sekedar merespon lingkungannya secara instingtual dan langsung, namun secara intelektual mampu mengendalikan refleks biologis menjadi respons-respons interpretatif dan bahkan manipulatif. Dengan cara ini manusia tidak semata-mata hidup dalam dunia fisik semata-mata, namun hidup juga dalam suatu dunia simbolis.

\section{Konsep Identitas Diri}

Pada umumnya warna pink digunakan oleh perempuan untuk membentuk dan merepresentasikan identitas dirinya. Identitas diri pada tiap perempuan memiliki motif dan konsep yang berbeda-beda, namun pada umumnya mengarah pada sifat-sifat femininitas. Paradigma yang telah terbentuk memotivasi perempuan untuk menggunakan warna pink sebagai simbol yang mendukung atau mewakili sifat-sifat feminin (cantik, cute dan manis), (Kobayashi, 1998). Seperti kesimpulan Chaney (1996) bahwa gaya hidup selanjutnya merupakan cara-cara terpola dalam menginvestasikan aspek-aspek tertentu melalui kehidupan sehari-hari dengan nilai sosial atau simbolik, dapat dikatakan bahwa gaya hidup adalah cara bermain dengan identitas. Konstruksi tersebut dibentuk melalui aspek norma, kondisi sosial masyarakat sekitarnya, tren dan gaya hidup. 


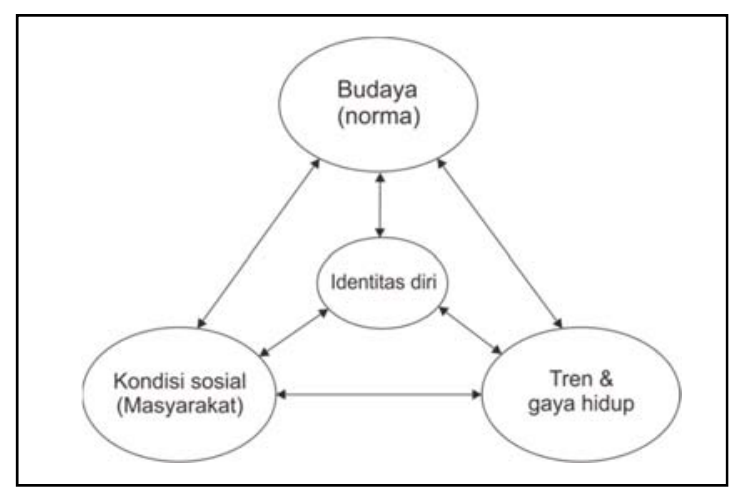

Gambar 1. Relasi Pembentuk Identitas Diri Sumber: Konstruksi Penulis (disimpulkan dari Burke) (2002)

Konsep diri yang dibentuk bertujuan untuk memposisikan diri agar dapat diterima pada kelompok atau masyarakat di sekitarnya. Perilaku tersebut merupakan gabungan dari aspek internal dan eksternal yang membentuk identitas diri, yaitu relasi individu dengan struktur sosial yang mengelilinginya. Burke (2002) memandang bahwa ketika kondisi eksternal dan internal ini bergabung, maka dinamisasi identitas seseorang akan terjadi. Interaksi yang terbentuk dari relasi disekitarnya akan menghasilkan keputusan berupa suatu tindakan (perilaku membentuk identitas diri).

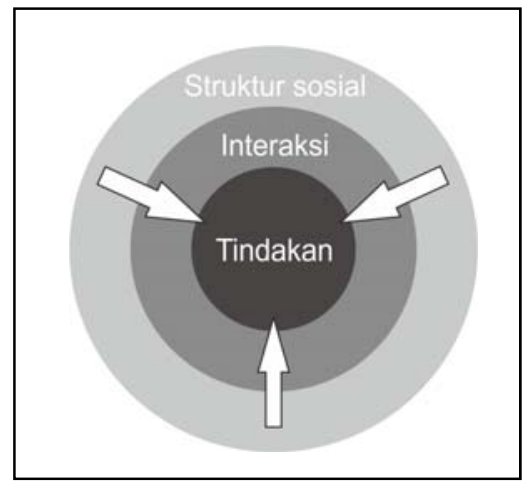

Gambar 2. Interaksi sosial

Sumber: Konstruksi Penulis (disimpulkan dari Burke) (2002)

Konstruksi sosial yang membentuk simbol femininitas pada warna pink menyebabkan terjadinya eksklusifitas antara warna tersebut dengan perempuan. Terdapat apresiasi yang berbeda di masyarakat terhadap laki-laki dan perempuan saat menggunakan warna tersebut. Seorang laki-laki yang menggunakan atribut berwarna pink cenderung diapresiasi secara negatif, seperti anggapan seorang gay atau transgender. Sebaliknya pada perempuan, cenderung mendapatkan apresiasi yang positif dan dianggap sebagai sesuatu yang wajar. Dampak dari eksklusifitas menyebabkan terjadi perilaku diferensiatif terhadap benda/obyek berwarna pink yang cenderung diapresiasi sebagai benda/obyek bersifat feminin dan milik perempuan.

\section{Konstruksi Sosial Terhadap Perilaku Gender Sebelum Abad 20}

Perkembangan warna pink dari waktu ke waktu pada umumnya merupakan ekspresi yang tidak dapat dipisahkan dari asosiasi terhadap sifat-sifat gender. Seperti contoh sebelum abad 
ke-20 di Eropa dan Amerika, warna pink cenderung digunakan laki-laki (terutama anak-anak) disebabkan jenis pigmen warna pink merupakan derivasi dari warna merah yang berkonotasi berani, sehingga warna pink dianggap bermakna keberanian atau semangat muda. Sifat keberanian dan semangat merupakan kategori dari sifat-sifat maskulin di dalam budaya patriarki. Sedangkan perempuan (terutama anak-anak) cenderung menggunakan warna biru muda, karena dianggap sesuai dengan kategori sifat perempuan yang lemah dan lembut. Selain itu pola asosiasi warna tersebut diyakini pula akibat pengaruh dari agama Katolik, yang bertolak dari beberapa lukisan sosok Jesus direpresentasikan menggunakan busana berwarna pink, sedangkan perawan Maria menggunakan busana berwarna biru. (Paoletti, 2012).

Sudut pandang masyarakat terhadap pola pemaknaan warna pink merupakan cerminan dari sistem budaya patriarki yang memiliki peranan kuat dalam menempatkan posisi gender (lakilaki dan perempuan) berdasarkan sifat-sifat yang telah terbentuk. Kehidupan sosial pada masa itu sangat bersifat androsentris (berpusat pada laki-laki), bagi Jones (1998) kondisi tersebut menempatkan posisi perempuan sebagai subordinasi yang dimarjinalkan dalam segi kultural dan sosial. Sehingga dalam sistem budaya patriarki terdapat kelas yang berbeda antara laki-laki sebagai kelas utama, dan perempuan di bawahnya. Hal tersebut menurut Moore (1988) disebabkan stereotype yang dibangun oleh konstruksi sosial mengarah pada perempuan yang mewarisi sifat feminin, yaitu emosional, pasif, inferior, bergantung, lembut, dengan peran yang terbatas pada bidang keluarga. Sedangkan laki-laki dinilai mewarisi sifat-sifat maskulin, yaitu rasional, aktif, superior, berkuasa, keras, dan menguasai peran masyarakat.

Perbedaan kelas/hierarki dalam sistem sosial menciptakan sistem aturan yang menentukan pola perilaku perempuan, sehingga hak dan posisi perempuan dibatasi dan dikendalikan oleh konstruksi sosial. Sistem pada budaya patriarki menentukan bagaimana cara perempuan bersikap dan berperilaku dalam kehidupan sosial sehari-hari, bertolak pada paradigma bahwa perilaku tersebut merupakan cerminan sifat-sifat ideal femininitas. Diantaranya seperti bagaimana perempuan bersikap terhadap laki-laki, perempuan bersikap terhadap perempuan, sikap perempuan di meja makan, sikap perempuan di tempat umum, tata cara berpakaian, berbicara, serta berjalan.

Konstruksi sosial menempatkan perempuan sebagai kelas dua dengan posisi sebagai obyek yang bersifat politis maupun sebagai obyek visual. Obyek politis seperti salah satu contoh yang diutarakan Said (1977) pada masa kolonialisme, dengan berdalih demi keselamatan perempuan dan anak-anak Inggris, proses agresi Inggris terhadap pemberontakan penduduk India memposisikan Inggris sebagai pihak yang terhormat dengan membela kehormatan diri melawan perilaku barbar penduduk pribumi India. Kasus tersebut memposisikan perempuan pada dua kondisi yang kontradiktif, satu sisi seakan-akan berada pada posisi terhormat, namun pada sisi lain justru merupakan obyek tameng politik untuk kepentingan laki-laki.

Sedangkan posisi perempuan sebagai obyek visual membentuk perwujudan ideal perempuan dari sudut pandang laki-laki, seperti pada abad 19 di mana perempuan dianggap cantik apabila memiliki image rapuh. Salah satu dampaknya terlihat pada perkembangan fashion dengan tren desain yang menampilkan kerapuhan perempuan melalui pemilihan jenis kain busana yang tipis, berwarna pucat, dan belahan dada yang rendah. Selain itu, posisi perempuan sebagai subordinasi menciptakan batasan-batasan yang menyebabkan terdapat perbedaan hak antara laki-laki dan perempuan, diantaranya adalah hak berpendidikan, hak penguasaan harta, hak bersuara, hak bekerja pada posisi tertentu dan hak memilih. Sistem tersebut kemudian membentuk pola perilaku yang membedakan antara cara berperilaku lakilaki dan perempuan di tengah-tengah masyarakat, termasuk pada sudut pandang dalam memaknai warna pink. 


\section{E. Transformasi Perilaku Sosial}

Periode awal abad ke 20 ditandai dengan terjadinya Perang Dunia I (tahun 1914-1918) dan Perang Dunia ke II (tahun 1939-1945) yang berdampak besar terhadap tatanan sosial, khususnya di negara-negara Eropa. Dampak sosial akibat perang menyebabkan terjadi perubahan revolusioner terhadap perilaku sosial, terutama pada perempuan. Sebab pada masa Perang Dunia, muncul kelas pekerja baru perempuan dalam jumlah besar yang bekerja menggantikan posisi laki-laki yang pergi berperang.

Perubahan tersebut berpengaruh terhadap perilaku dan gaya hidup perempuan, sebab norma-norma yang membatasi kehidupan perempuan mulai terbuka. Posisi perempuan lebih independen, stereotip pada budaya patriarki yang menganggap kehidupan perempuan bersandar pada laki-laki mulai hilang. Posisi perempuan yang sebelumnya dianggap kurang berguna, kini mulai diperhitungkan. Selain itu hak perempuan mulai terbuka pada beberapa sektor pekerjaan yang sebelumnya hanya ditempati laki-laki, seperti industri berat (senjata, mesin, kendaraan perang) dan perkantoran. Perempuan mulai mendapatkan hak suara, hak berpendidikan, dan hak mengutarakan pendapat.

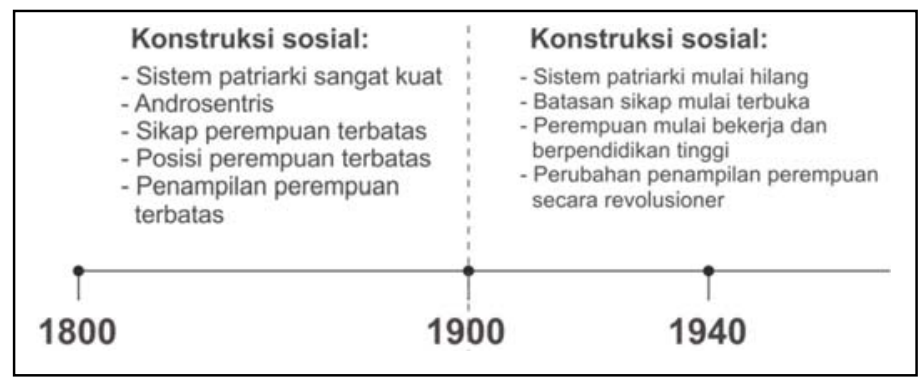

Gambar 3. Konstruksi Sosial

Sumber: Konstruksi Penulis (2015)

\section{F. Pergeseran Makna Warna Pink}

Terjadinya pergeseran makna warna pink pada dasarnya berkaitan erat dengan sistem budaya patriarki, sebab konotasi warna pink yang sejajar dengan sifat maskulin menyebabkan terdapat fungsi hierarki terhadap gender. Seperti yang terjadi di negara Inggris pada abad 19, anak laki-laki pada saat itu dianggap sebagai seorang laki-laki (men) yang masih kecil, sehingga para orang tua memberikan busana berwarna pink pada anak laki-laki, adaptasi warna merah yang digunakan oleh orang-orang dewasa pada seragam kerajaan dan pakaian militer (Paoletti, 2012)

Proses pergeseran makna warna pink mulai terjadi setelah munculnya dominasi warnawarna simbol negara dan/atau atribut militer pada saat Perang Dunia I dan II. Dominasi warnawarna tersebut pada umumnya mengarah pada sifat-sifat maskulin yang terus menerus ditampilkan, dibentuk, dan diperkuat demi menciptakan semangat perjuangan dan rasa nasionalisme. Di Amerika dominasi warna yang muncul saat Perang Dunia ialah warna biru, diantaranya berasal dari warna bendera Amerika, warna seragam angkatan laut, dan warna pakaian kerja (boilersuit) pada dunia industri. Seiring berjalannya waktu warna-warna yang dekat dengan dunia perang menyebabkan persepsi laki-laki terhadap jenis warna maskulin berubah, sebab efek dari dominasi warna simbolik dapat merubah sudut pandang seseorang akibat terbiasa pada pola pengalaman visual. Menurut Bourdeau (1998) efek dominasi simbolik diberlakukan bukan dalam logika murni kesadaran yang sanggup menyadari, tetapi lewat skema-skema persepsi, apresiasi dan aksi yang menyusun habitus-habitus, dan mendasari suatu relasi pengetahuan di luar segala keputusan-keputusan kesadaran dan kendali keinginan. 
Perubahan persepsi terhadap warna maskulin menyebabkan warna pink kehilangan bentuk pemaknaan, selain disebabkan dominasi warna baru maskulin, terdapat pengaruh yang kuat dari Jerman (Nazi) pada saat menggunakan warna pink sebagai simbol untuk menandai kelompok gay (dengan konotasi negatif). Kuatnya pengaruh Jerman saat Perang Dunia pada akhirnya mampu menghegemoni perspektif masyarakat terhadap pemaknaan warna pink yang dianggap feminin. Sekain itu, simbol maskulinitas pada saat perang berperan sangat penting terhadap moral pasukan, sehingga unsur-unsur maskulinitas akan terus direproduksi, dan unsur yang dianggap membentuk citra feminin akan dikesampingkan.

Di sisi lain, warna pink justru mulai banyak digunakan perempuan sebagai simbol ekspresi kebebasan, terutama pada perempuan-perempuan modern di awal abad 20. Maskulinitas pada warna pink yang semula berkonotasi berani dan/atau semangat muda, kemudian diadaptasi sebagai bentuk ekspresi diri perempuan modern yang mulai berani dan terbuka. Pada perkembangannya warna pink kemudian menjadi simbol ekspresi baru yang tidak berasosiasi dengan gender tertentu, sebab bentuk maskulinitas pada warna pink mulai bergeser, dan perempuan cenderung menggunakan jenis warna pink yang bersifat lembut (pink pastel, pink pale) yang masih mencerminkan sifat-sifat feminin.

Masa Perang Dunia I dan II menyebabkan perkembangan warna terbatas, warna-warna yang umum digunakan pada saat itu lebih sederhana dan seragam, dengan dominasi warna biru laut, khaki dan coklat (pengaruh dari warna-warna kamuflase pada pakaian perang). Pada masa Perang Dunia pergeseran makna warna pink mulai terjadi, warna pink digunakan sebagai ekspresi bentuk kemampuan dan posisi hierarki yang sebelumnya hanya terdapat pada laki-laki. Penggunaan warna pink merupakan simbol ekspresi sisi maskulinitas dalam diri perempuan yang direproduksi menjadi simbol femininitas baru.

Pada tahun 1950an pergeseran makna warna pink mencapai puncak bentuk femininitas, warna pink menjadi simbol optimisme pasca dominasi sifat maskulin pada saat Perang Dunia. Dapat diamati pada tren warna pink yang berkembang dan menjadi warna yang populer di tahun 1950an, dunia perfilman yang menghegemoni paradigma masyarakat semakin memperkuat image feminin warna pink melalui beberapa film, salah satunya film Funny Face yang secara eksplisit mengampanyekan warna pink sebagai warna baru untuk perempuan, berikut kutipan monolog di awal film Funny Face. "Pikirkan pink, merah itu mati, biru telah berlalu, hijau tidak pantas, coklat itu tabu. Dan tidak ada alasan lagi untuk menggunakan warna plum (ungu) atau puse (ungu pucat), atau chartreuse (kuning kehijauan). Pikirkan pink, lupakan kata Dior, tentang hitam dan rust (terakota). Pikirkan pink, tampilan jaman sekarang (new look) tidak perduli ukuran payudara. Saya tidak akan menduga-duga (tren) apa yang dipikirkan para perempuan, tapi saya akan memberitahukan apa yang harus mereka pikir, pikirkan pink" (Funny Face, 1957)

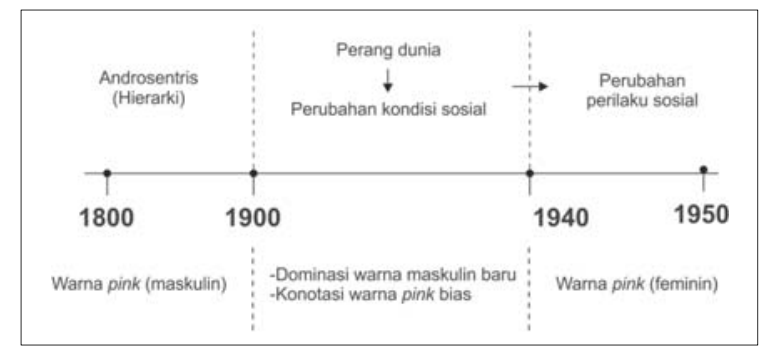

Gambar 4. Proses Pergeseran Makna Ke 1 (maskulin berubah menjadi feminin). Sumber: Konstruksi Penulis (2015)

Dalam kutipan kalimat "biru telah berlalu" semakin mempertegas bahwa sudut pandang pemaknaan terhadap warna maskulin dan feminin telah mengalami perubahan, warna biru yang 
sebelumnya cenderung berkonotasi feminin telah bergeser menjadi warna maskulin, begitu pula sebaliknya pada warna pink yang berubah menjadi warna feminin.

\section{G. Makna Ganda Warna Pink Tahun 1950}

Warna pink yang digunakan sebagai simbol ekspresi pada tahun 1950an merupakan bentuk simbol yang berhasil digunakan dan berdampak besar terhadap perkembangan tren produkproduk gaya hidup, seperti yang telah dijelaskan pada bab sebelumnya. Diantaranya seperti peralatan rumah tangga, furnitur, kitchen set, appliance, atribut kamar mandi, hingga pakaian dan mainan. Simbol ekspresi tersebut pada umumnya mengarah pada ekspresi keceriaan dan playfull di dalam koridor femininitas.

Pada pertengahan tahun 1950an warna pink kemudian populer digunakan oleh laki-laki, disebabkan warna pink menjadi warna yang sangat populer pada dekade 50an dan mendominasi berbagai produk gaya hidup, selain itu muncul budaya konsumtif pada masyarakat Amerika akibat kondisi ekonomi yang sedang berkembang serta pengaruh industri hiburan (film, musik) yang kemudian diadaptasi ke dalam gaya hidup masyarakat. Pola-pola yang ditampilkan pada industri hiburan membentuk budaya baru pada laki-laki untuk tampil lebih ekspresif, seperti yang terdapat pada gaya hidup perempuan. Pola budaya tersebut terjadi bersamaan dengan perkembangan warna pink yang menjadi simbol ekspresi perempuan pada saat itu, sehingga warna pink kemudian populer digunakan oleh laki-laki.

Konotasi feminin tetap menjadi karakter warna pink, namun dikombinasikan dengan karakter maskulin. Kombinasi karakter tersebut menampilkan sisi femininitas pada diri lakilaki yang pada era-era sebelumnya dianggap tabu. Yaitu bentuk perilaku yang mengarah pada gaya metroseksual dan/atau flamboyan yang mengadaptasi perilaku gaya hidup perempuan, seperti budaya mempercantik (berdandan), merawat, dan menjaga penampilan diri untuk membentuk suatu identitas diri. Bagi Fromm (1947), Identitas diri dapat dibedakan tetapi tidak dapat dipisahkan dari identitas sosial seseorang dalam konteks komunitasnya.

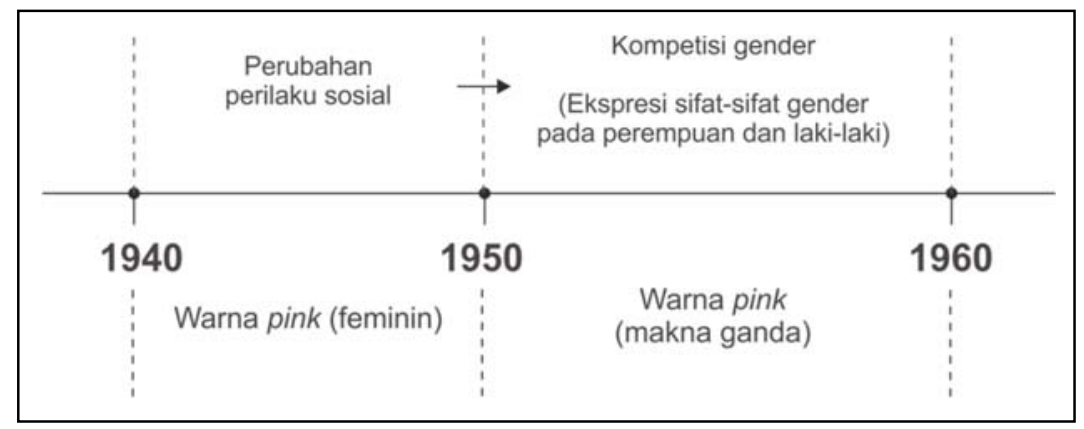

Gambar 5. Proses Pergeseran Makna Ke 2

(feminin berubah menjadi bermakna ganda) Sumber: Konstruksi Penulis (2015)

Selain mahkluk individual yang membangun identitas dirinya berdasarkan konsep atau gambaran dan cita-cita diri ideal yang secara sadar dan bebas dipilih, manusia sekaligus juga mahkluk sosial yang dalam membangun identitas dirinya tidak dapat melepaskan diri dari norma yang mengikat semua warga masyarakat tempat ia hidup dan peran sosial yang diembannya dalam masyarakat tersebut. Sebab dalam teori identitas sosial, seorang individu tidaklah dianggap sebagai individu secara mutlak satu dalam kehidupannya. Individu merupakan bagian dari kelompok tertentu baik disadari maupun tidak disadari. Konsep identitas 
sosial adalah bagaimana seseorang itu secara sosial dapat didefinisikan (Verkuyten, 2005). Proses pembentukan identitas diri tersebut dimanifestasikan melalui ekspresi yang dilakukan dengan berbagai macam bentuk, salah satunya dengan menggunakan warna pink.

Makna ganda pada warna pink merupakan pola sudut pandang yang dibentuk oleh masingmasing gender dengan sudut pandang yang berbeda. Pada sudut pandang perempuan, warna pink merupakan simbol ekspresi kemandirian perempuan, manifestasi dari perubahan perilaku sosial pada saat Perang Dunia. Warna pink yang sebelumnya bersifat hierarkis (akibat konotasi maskulin) digunakan perempuan sebagai simbol kesetaraan gender (kemampuan, hak dan posisi kultural). Sedangkan pada sudut pandang laki-laki, warna pink merupakan alat berekspresi untuk menampilkan sisi feminin pada diri maskulin.

Aktifitas kompetisi gender dengan menggunakan warna dapat terjadi akibat proses interaksi simbolik, bagi Mead (1934) hal tersebut disebabkan manusia membentuk dan mengatur perilaku mereka dengan mempertimbangkan ekspektasi orang lain yang menjadi mitra mereka melalui komunikasi dan pertukaran simbol yang diberi makna. Makna dan simbol yang telah diinterpretasi kemudian dilanjutkan dengan tindakan dan interaksi-interaksi selanjutnya yang kemudian menjadi kebiasaan manusia sehari-hari. Menurut Cassirer (1944) dunia manusiawi selain mengikuti hukum-hukum biologis juga memiliki karakteristik baru yang menandai ciri khas manusia. Lingkaran fungsional manusia tidak hanya berkembang secara kuantitatif, tetapi juga mengalami perubahan-perubahan kualitatif. Manusia mampu menemukan cara baru untuk menyesuaikan diri dengan lingkungannya, dalam hal ini pola pemaknaan warna pink berasal dari perubahan kondisi sosial yang berdampak pada perubahan perilaku sosial, perubahan tersebut berdampak pada perspektif dalam memaknai warna pink sesuai dengan kebutuhannya.

Kondisi dualisme makna tersebut kemudian semakin diperkuat oleh perkembangan kultur pop, warna pink pada umumnya digunakan pada beberapa karya grafis dengan tema-tema yang bersifat provokatif, ambigu, sindiran dan parodi. Tren terhadap pemaknaan ganda warna pink mencapai puncaknya pada dekade 1960an, disebabkan perkembangan budaya pop dengan subkultur barunya yang menciptakan budaya psychedelic dengan karakteristik warna-warna keras yang saling bertabrakan, dan warna pink dengan tone keras/shocking (hot pink, shocking pink) merupakan salah satu warna yang umum digunakan. Tren tersebut menyebabkan asosiasi gender pada warna pink menjadi bias, sebab warna pink tidak lagi berfungsi sebagai simbol gender.

\section{H. Perubahan Masif Femininitas}

Seiring perkembangan waktu, asosiasi warna pink yang bias terhadap gender pada dasarnya tidak berpengaruh terhadap konotasi femininitas pada warna pink. Sebab konotasi femininitas pada warna pink telah berkembang dan menyebar melalui proses adaptasi yang dikembangkan oleh masyarakat dengan pola rhizome yang mengesampingkan akar budaya dan sisi historisnya, hingga terbentuk suatu budaya baru yang berkembang dan/atau hasil kolaborasi dengan budaya lainnya yang menghasilkan turunan produk-produk budaya baru (berwarna pink) dengan pendangkalan makna.

Kebudayaan yang dibangun berdasarkan prinsip rhizome menolak struktur organisasi dari sistem akar dan sumber asli, kebudayaan tersebut tidak pernah berhenti menghubungkan rantai semiotik, tanda, simbol, makna, pengetahuan, dan relasi-relasi sosial yang baru dan kreatif. Jenis kebudayaan yang tidak pernah berhenti berhubungan, berinteraksi, berdialog, bersaing, berubah, berpindah. Dalam model ini budaya menyebar seperti air, menyebar hingga ke ruang yang tersedia atau menetes ke bawah menuju ruang baru melalui celah, mengikis apa saja yang dilewati. Budaya permukaan dapat terganggu dan pindah, namun tetap meninggalkan jejak. 
Terjadinya pergeseran makna warna pink pada dasarnya terjadi akibat kecemburuan sosial perempuan terhadap budaya patriarki yang menciptakan hierarki antara laki-laki dengan perempuan, sehingga menyebabkan ketimpangan hak dan kewajiban. Warna pink yang semula merupakan warna maskulin dianggap menjadi salah satu alat untuk mengekspresikan kemampuan diri akibat perubahan perilaku sosial pada saat Perang Dunia. Kemampuan dan kesempatan perempuan melakukan pekerjaan laki-laki merupakan titik balik yang merubah konstruksi sosial secara revolusioner. Dari ketiga proses transformasi di atas, dapat dipetakan proses transformasi berdasarkan periode, penyebab, serta dampak yang dihasilkan pada gambar berikut ini:

\begin{tabular}{|c|c|c|c|c|c|}
\hline Periode & \multicolumn{2}{|c|}{1900} & 1950 & 1970 & 1980 \\
\hline $\begin{array}{c}\text { Transformasi } \\
\text { warna pink }\end{array}$ & Hirarki & Revolusi & $\begin{array}{l}\text { Persamaan } \\
\text { (equality) }\end{array}$ & $\begin{array}{l}\text { Kebebasan } \\
\text { (liberty) }\end{array}$ & \\
\hline $\begin{array}{c}\text { Kondisi } \\
\text { sosial }\end{array}$ & $\begin{array}{l}\text { Gender laki-laki } \\
\text { diatas perempuan } \\
\text { (Patriarki) }\end{array}$ & $\begin{array}{l}\text { Perubahan sosial gender: } \\
\text { - Bekerja } \\
\text { - Pendidikan } \\
\text { - Perilaku }\end{array}$ & $\begin{array}{l}\text { Persamaan hak gender: } \\
\text { - Membentuk identitas diri } \\
\text { - Berdandan } \\
\text { - Ekspresif }\end{array}$ & $\begin{array}{l}\text { Bias identitas gender: } \\
\text { - LGBT Movement } \\
\text { - Feminisme } \\
\text { - Black people movement }\end{array}$ & \\
\hline
\end{tabular}

Gambar 6. Timeline Transformasi Pergeseran Makna Warna Pink Sumber: Konstruksi Penulis (2015)

Berikut rangkuman perubahan kondisi sosial di Amerika, yang berdampak terhadap perilaku sosial dan pola pemaknaan terhadap warna pink pada tabel:

Tabel 3. Proses Transformasi Sosial di Amerika

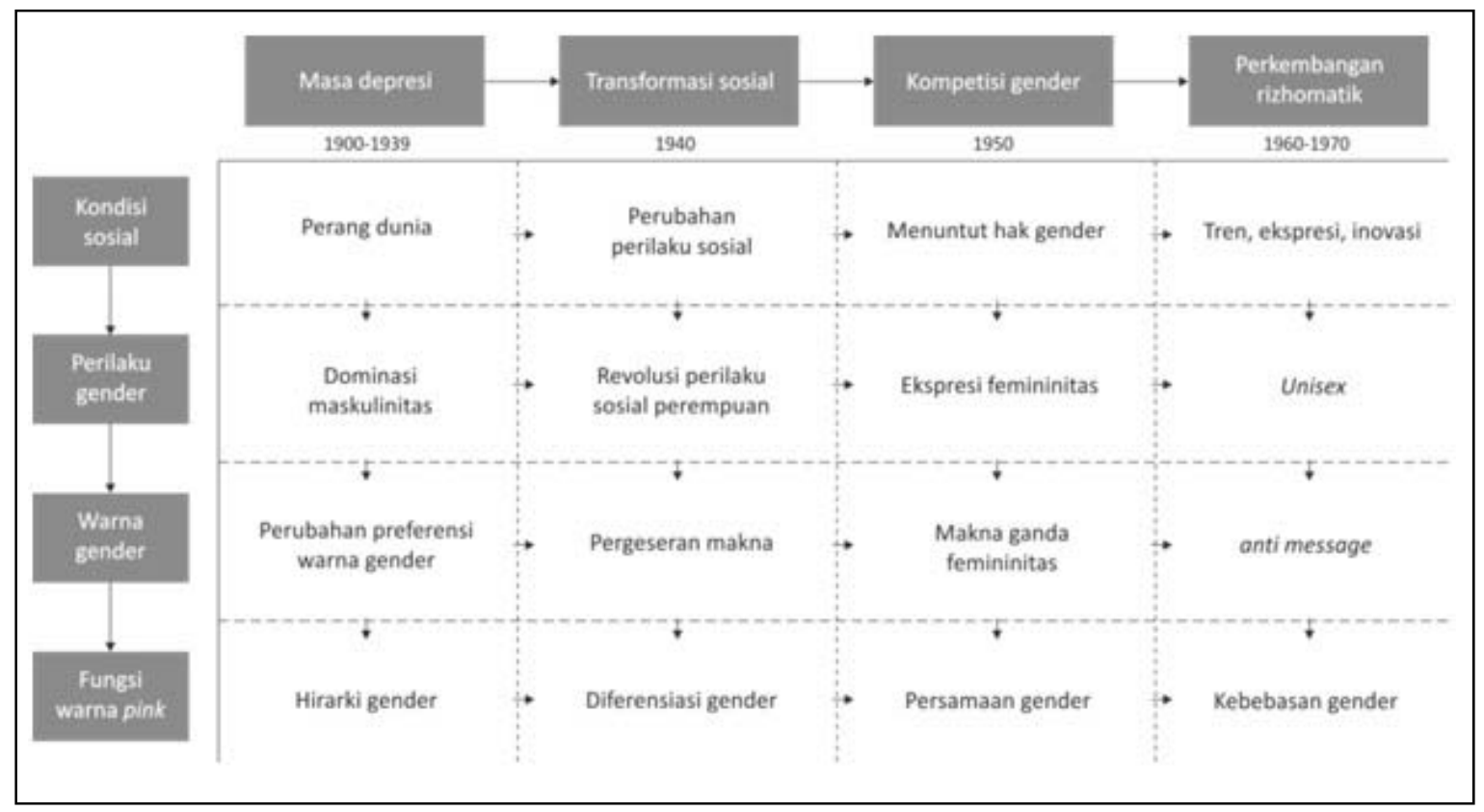

Sumber: Konstruksi Penulis (2015) 


\section{KESIMPULAN}

Bila disimpulkan, pergeseran makna pada warna pink merupakan hasil dari perilaku sosial yang terjadi di Amerika, yaitu suatu perilaku kompetisi gender dampak dari kondisi sosial yang dipengaruhi oleh berbagai aspek, terutama pengaruh besar dari perang dunia I dan II (praperang, masa peperangan dan pasca terjadinya perang). Perkembangan dari perilaku kompetisi gender di Amerika dapat dikelompokkan ke dalam 3 tahap, dimulai sejak awal abad ke-20 hingga akhir tahun 1970an.

Pergeseran makna yang pertama terjadi akibat dari perubahan perilaku sosial yang terjadi pada perempuan, dampak dari perubahan kondisi sosial di awal abad ke-20 hingga pasca Perang Dunia II. Pada saat itu mayoritas laki-laki meninggalkan rutinitas dan pekerjaannya (terutama industri yang pada masa itu identik dengan pekerjaan laki-laki) untuk ikut berperang, dampak dari hal tersebut menyebabkan perempuan mulai mengisi dan menggantikan pos-pos pekerjaan yang ditinggalkan laki-laki. Diantaranya bekerja pada pabrik-pabrik alat berat, pabrik-pabrik senjata, dan pekerjaan administratif. Perubahan perilaku sosial yang revolusioner tersebut menyebabkan perempuan merasa sejajar dalam hal gender, perempuan merasa memiliki hak yang sama karena mampu berperan dan beraktifitas seperti laki-laki.

Pada saat itu warna biru dan warna khaki (coklat tanah) merupakan warna yang dominan digunakan laki-laki dan lebih bersifat maskulin, salah satunya disebabkan warna tersebut digunakan sebagai warna seragam militer. Sebaliknya warna pink yang sebelumnya lebih bersifat maskulin (bermakna semangat dan ekspresif), justru mulai digunakan oleh perempuan. Warna pink digunakan sebagai simbol ekspresi dan semangat, karena perempuan merasa mampu dan sejajar dengan laki-laki. Pola kecenderungan tersebut merupakan proses pergeseran makna yang pertama, hingga pasca Perang Dunia ke II konotasi warna pink kemudian semakin bergeser ke sifat-sifat femininitas.

Pergeseran makna yang kedua mulai terjadi pada pertengahan tahun 1950an hingga puncaknya pada tahun 1960. Terjadinya pergeseran makna disebabkan perubahan perilaku sosial pada laki-laki yang mengadaptasi pola-pola gaya hidup perempuan seperti budaya berdandan, merawat diri, dan orientasi dalam mengutamakan penampilan. Adaptasi tersebut menciptakan pola gaya hidup yang mengarah pada ekspresi femininitas dari tubuh maskulin. Perubahan perilaku sosial tersebut dampak dari kemajuan ekonomi yang terjadi di Amerika. Warna pink dianggap sebagai cerminan semangat dan ekspresi diri, pasca era Perang Dunia yang suram. Karena sebelumnya warna pink dianggap berhasil digunakan oleh perempuan sebagai sebuah simbol ekspresi. Fenomena tersebut menyebabkan terjadinya pergeseran makna yang kedua, yaitu dari konotasi feminin berubah menjadi feminin yang bermakna ganda.

Pergeseran makna yang ketiga terjadi antara pertengahan tahun 1960 hingga tahun 1970an, makna warna pink kemudian masif berkonotasi femininitas (memiliki sifat-sifat feminin seperti kelembutan, kasih sayang) dan bertahan hingga saat ini. Perubahan tersebut akibat dari pengaruh isu-isu sosial yang berkembang, seperti isu lingkungan, masa resesi, gerakan feminisme, dan akibat dari kebutuhan industri dalam memetakan arah produksi dengan membentuk segmentasi pasar melalui produk-produk konsumsi.

\section{DAFTAR PUSTAKA}

Bourdieu, P. (1998). La Domination Masculine. SEUIL

Burke, Peter, Stets, Jan, (1998). Identity Theory and Social Identity Theory. (Washington State University)

Cassirer, E. (1962). An Essay on Man: An Introduction to a Philosophy of Human Culture. Yale University Press.

Chaney, D. (1996). Lifestyles. Psychology Press 


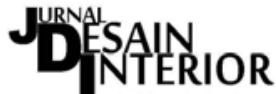

Vol. 2, No. 2, Desember 2017, pISSN 2527-2853, eISSN 2549-2985

Fromm, E. (1941). Escape from freedom. New York: Avon Books.

Hallock, Joe. (2003). Colour Assignment.

Hulbert, Anya \& Ling, Yazhu. (2007). Biological Component of Sex Differences in Colour Preference.

Jackson, S. \& Jones, J. (1998). Contemporary Feminist Theories. New York University Press.

Kobayashi, S. (1998). Colorist: A Practical Handbook for Personal and Professional Use. Published by Kodansha International Ltd.

Mahnke, F. H. (1996). Colour, environment and Human Response. An Interdisciplinary Understanding of Colour and its Use as a Beneficial Element in the Design of the Architectural Environment, Van Nostrand Reinhold, NY.

Mead, G. H. (1934). Mind, self, and society. Chicago: University of Chicago Press.

Moore, H. L. (1988). Feminism Anthropology. University of Minnesota Press.

Paoletti, J. (2012). Pink and blue: Telling the boys from the girls in America. Indiana University Press

Said, Edward. (1977) Orientalism. London: Penguin Books.

Verkuyten, M. (2005). The Social Psychology of Ethnic Identity. Psychology Press. 
Moh. Faishol Fuady

Pergeseran Makna Warna Pink dari Maskulinitas Menjadi Femininitas di Amerika Serikat Tahun 1940-1970 